\title{
WISSELING IN HET PAVILJOEN \\ 1616 / ARITA JAPAN
}

Ongeveer 400 jaar geleden werd er voor het eerst porselein in Japan gemaakt. Dat gebeurde in het plaatje Arita in Zuid-Japan. In het omliggende gebied werden al vanaf de $\mathrm{I}^{\mathrm{e}}$ eeuw steengoed gebruiksvoorwerpen gemaakt, maar het duurde tot het begin van de $17^{\mathrm{e}}$ eeuw voordat er porselein vervaardigd kon worden, ontwikkeld met hulp van Koreanen die meegevoerd waren naar Japan na de mislukte invasies door de krijgsheer Hideyoshi in 1592 en I597. In de bergen rond Arita werd porseleinsteen gevonden en het was waarschijnlijk in de jaren na I6Io dat de porseleinindustrie op gang kwam, die tot op de dag van vandaag bestaat.

Japans porselein is in Nederland vooral bekend van het blauwwitte goed, vaak in Chinese stijl, van het gekleurde goed in de Imari- of Kakiemonstijlen. Het project I6I6 / arita japan, dat voor 2016 in het leven werd geroepen ter gelegenheid van het 40o-jarig porselein jubileum, slaat echter een andere weg in. Het doel van het I6I6 project is om Arita porselein een plek in de designwereld te geven. De 'I6I6' in de naam heeft behalve het jaartal ook nog een andere betekenis: voor het project werden I6 ontwerpers uit Japan en Europa samen met I6 werkplaatsen uit Arita aan het werk gezet, om met gebruik van de grote kennis over materialen en technieken die in Arita aanwezig is, eigentijdse en vernieuwende ontwerpen te ontwikkelen.

Als creative director van het project werd de ontwerper Teruhiro Yanagihara aangesteld. Hij verkent nieuwe richtingen door te experimenteren met klei en de gebruiksmogelijkheden van keramiek. Tegenover zijn werk staat het design dat is ontwikkeld door het Nederlandse ontwerpersduo Scholten \& Baijings. Hun Colour Porcelain gebruikt kleur en vorm voor een dialoog tussen toegepaste kunst en gebruiksgoed voor alledag. Zij zijn de coördinerende krachten achter het project, maar in het Aziatisch paviljoen zijn de producten van alle I6 ontwerpers te zien, van 22 april tot half oktober. Ze worden getoond in samenhang met porselein uit de museumcollectie, gevat in een speciaal ontworpen kast, die de lange schilderingen- of kimono-vitrine op de benedenverdieping van het paviljoen zal vullen.

In de vitrine hiertegenover zal een andere kant van Arita porselein aan bod komen: Kakiemon-porselein. Centraal in de vitrine zal een groot stuk worden getoond van de $15^{\mathrm{e}}$ generatie Kakiemon pottenbakkers. Kakiemon $\mathrm{XV}$, zoals hij wordt genoemd, heeft na het overlijden van zijn vader in 2013 de leiding van de prestigieuze werkplaats overgenomen en staat nu voor

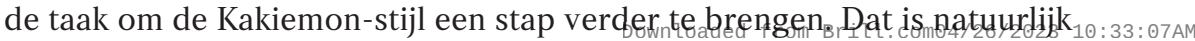




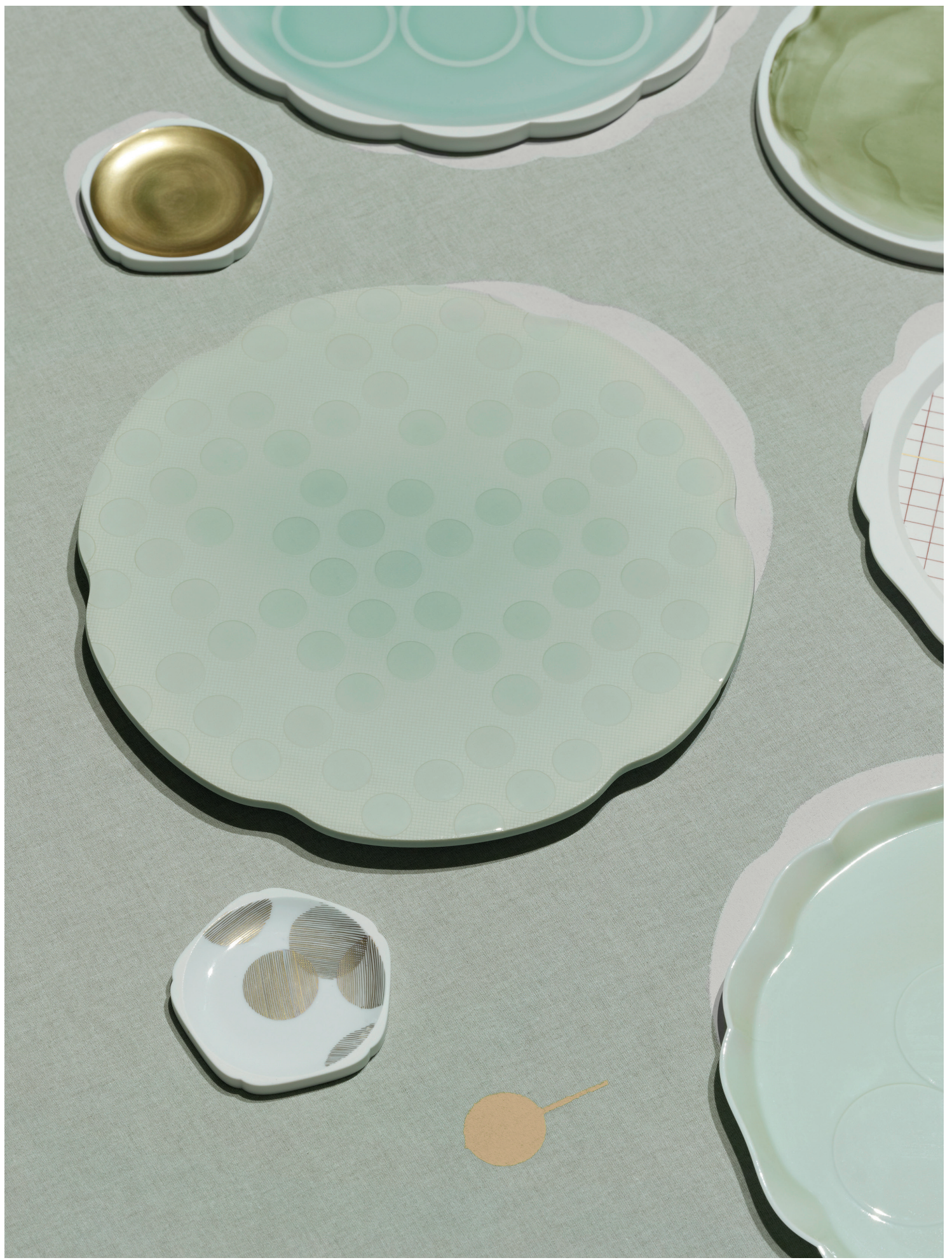

\section{6/ collectie}

Scholten \& Baijings

Fotografie: Scheltens

\& Abbenes 
niet eenvoudig. De Kakiemon-stijl van porselein maken en versieren is benoemd tot Japans cultureel erfgoed en die status brengt met zich mee dat de traditie behouden moet blijven. Aan XV nu de eer om binnen de grenzen van de traditie een eigen signatuur te ontwikkelen. Het zal dan ook interessant zijn om in het Aziatisch paviljoen het nieuwe Kakiemon te kunnen zien, waar het werk van XV zal worden omgeven door I $7^{\mathrm{e}}$-eeuwse exemplaren uit de Kakiemon-collectie van het Rijksmuseum. Het overgrote deel van het Kakiemon in het Rijksmuseum werd verzameld door de eerste VVAK-voorzitter Westendorp. Voor hem was de studie en verwerven van Kakiemon 'feitelijk mijn liefste hobby' en ik stel me voor dat hij verguld zou zijn geweest om zijn collectie in deze context getoond te zien worden.

Zo is er zowel bij de opstelling van het moderne porselein als in de Kakiemon-vitrine sprake van een dialoog tussen Japan en Nederland, passend voor een kunstnijverheidsvorm die zo beeldbepalend is geweest in de lange betrekkingen tussen beide landen.

NOOT

I Zie Aziatische Kunst 43/3-4 (2013), pp. 72-80. 